\title{
THE ROLE OF DIGITAL MARKETING AND BUSINESS CAPITAL IN INCREASING INCOME OF MSMES IN DENPASAR CITY IN THE CONDITIONS OF COVID-19
}

\author{
Pratama I Gede Surya*, Idawati Ida Ayu Agung \\ Faculty of Economics and Business, Warmadewa University, Denpasar, Indonesia \\ ${ }^{\star}$ E-mail: igedesuryapratama@gmail.com
}

\begin{abstract}
This study aims to determine the role of digital marketing and business capital in increasing Denpasar city income amid Covid-19. This study used 100 respondents who were selected using random sampling spread in Denpasar City, then the data were analyzed using multiple linear regression. The results of the simultaneous analysis show that the variables of digital marketing and business capital have a significant effect on increasing the income of MSMEs in Denpasar City. Meanwhile, the results of the partial analysis of digital marketing and business capital variables have a significant effect on increasing MSME income in Denpasar City. Digital Marketing is the dominant variable that affects the increase in income, so people will find it easier to get information about the products being sold so that the buying and selling transaction process increases. Purchases will increase and income will increase. Once with business capital, the higher the capital will increase the amount of additional production, thereby increasing income.
\end{abstract}

\section{KEY WORDS}

MSMEs, digital marketing, business capital, increased income.

In 2020, the whole world was hit by the corona virus (Covid-19) which made the whole world affected by the virus. Many countries have locked down, but there are still some countries that are reluctant to do lockdown in order to avoid a recession in a country.

In Indonesia The government itself does not do a lockdown but provides policies to regions to limit activities or activities outside the home that are considered unnecessary. However, the reality is that many from various sectors are experiencing the impact of Covid19 , and what is most felt by the community is the economic sector. The impact on the economic sector is also felt by people who experience layoffs (PHK) and also the decline in income from Micro, Small and Medium Enterprises (MSMEs).

The micro, small and medium enterprises (MSME) sector also has a contribution in terms of increasing the amount of gross domestic product. Until now, MSMEs are considered as an effective way to raise the level of the economy. The role of MSMEs since the 1998 monetary crisis can be said to be a saviour in the process of recovering the national economy, both in terms of encouraging the rate of economic growth and also in terms of employment (Ningsih, 2018). MSMEs are a source of livelihood for many people and are able to provide jobs for those who are educated and low-skilled and able to reduce poverty (Idawati and Pratama, 2020).

In the city of Denpasar, there were recorded that there were 32,026 MSMEs assisted by the Denpasar City Cooperatives Service in 2020, from various sectors. The large number of Micro, Small and Medium Enterprises (MSMEs) in Denpasar City is a separate asset that will strengthen the foundation of the regional economy, in essence it can be a source of income for local governments, besides that the participation of MSMEs can realize economic growth, equity, and increase people's income. job creation, and poverty alleviation

Maintaining stable income from MSMEs requires business capital in the form of financing funds with small fees / interest and also the need for Digital marketing so that these businesses can reach buyers or consumers who cannot directly shop offline to these sellers during this Covid-19 period. Business capital is a factor that has a fairly important role in the production process, because business capital is needed when entrepreneurs want to establish or run a new business or to expand an existing business. obtained (Utari and Dewi, 
2014). Digital marketing is also very much needed to increase sales and also increase revenue. Digital marketing at this time of Covid-19 really helps MSMEs and the community to make it easier and faster to carry out buying and selling transactions without the need to come to the store. Based on the phenomena written on the background above, the research questions are as follows: is there any influence of Digital Marketing on increasing MSME income in Denpasar City; is there an effect of Business Capital on increasing MSME income in Denpasar City.

\section{LITERATURE REVIEW}

Gitman et al. (2015) explains that working capital/business capital is the amount of current assets that are part of the investment that circulates from one form to another in a business activity. Abbass (2018) said that working capital/business capital is an investment in short-term assets or investment in current assets. Working capital can be categorized into two, namely gross working capital and net working capital. Gross working capital is total current assets, and net working capital is total current assets minus current liabilities.

Digital marketing is also defined as marketing activities that use internet-based media (Wardhana, 2015). Marketing activities cannot be separated from the influence of digital technology. The term digital-based marketing (digital marketing) has evolved from the initial activities of marketing goods and services using digital channels to a broader understanding, namely the process of acquiring consumers, building consumer preferences, promoting brands, nurturing consumers, and increasing sales (Sulaksono and Zakaria, 2020).

Income is a very important element in a business, because in doing a business, of course you want to know the value or amount of income earned during doing the business (Artini, 2019). If income increases then it illustrates that there is a development in a business.

\section{METHODS OF RESEARCH}

This research was conducted in Denpasar City, the main reason for choosing this location is the number of MSMEs in Denpasar City is the largest of several districts in Bali. The object of this research is the development of the influence of digital marketing, the business capital used on the income of MSMEs in the Denpasar City area. Data were collected by distributing questionnaires and supported by the results of interviews with respondents. The population in this study were all MSMEs in Denpasar City. The number of population taken in this study was 32,026 MSMEs and the number of samples was 100 MSMEs with a sampling technique using Stratified Random Sampling. Multiple linear regression data analysis techniques, The hypothesis in this study was tested using the simultaneous test ( $\mathrm{F}$-test) and partial test (t-test) to determine the effect between variables. The classical assumption tests used in this research are normality test, heteroscedasticity test, and multicollinearity test.

\section{RESULTS AND DISCUSSION}

There are 46 male respondents or $46 \%$, far less than 55 female respondents or $54 \%$. Judging from age, respondents aged 21 to 30 years were 17 people or $17 \%$, aged between 31 years to 40 years were 31 people or $31 \%$, aged between 41 to 50 years were 26 people or $26 \%$, and aged over 51 years as many as 26 people or $26 \%$. Judging from the length of business, respondents who have been in business for less than 1 year are 22 people or $22 \%$, respondents who have been in business for 1 year to 5 years are 38 people or $38 \%$ and respondents who have been in business for more than 5 years are 40 people or $40 \%$.

The results of the validity and reliability test showed that the questionnaire instrument proposed in this study through various questionnaire items was valid and reliable. Testing the relationship in the classical assumption test, namely: data normality test, multicollinearity, heteroscedasticity, and autocorrelation showed that the entire questionnaire instrument had met the requirements for hypothesis testing through regression. 
Table 1 - Characteristics of Respondents

\begin{tabular}{|l|l|l|}
\hline Information & Number of people) & Percentage (\%) \\
\hline Gender & & \\
Man & 46 & 46.0 \\
Woman & 54 & 54.0 \\
Total & 100 & 100.0 \\
\hline Age & & \\
$21-30$ Years & 17 & 17.0 \\
$31-40$ Years & 31 & 31.0 \\
$41-50$ Years & 26 & 26.0 \\
>51 Years & 26 & 26.0 \\
Total & 100 & 100.0 \\
\hline Long Running Business & & \\
< Year & 22 & 22.0 \\
$1-5$ Years & 38 & 38.0 \\
>5 Years & 40 & 40.0 \\
Total & 100 & 100.0 \\
\hline
\end{tabular}

Source: Data processed, 2020.

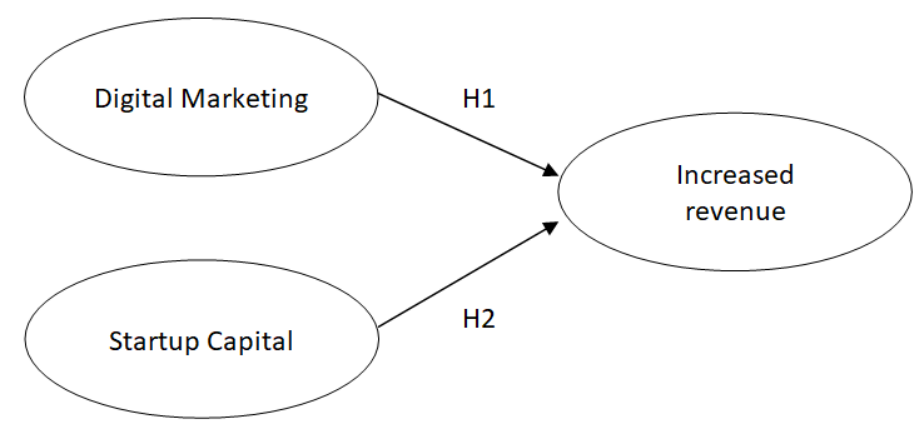

Figure 1 - Research Model

Table 2 - Regression Results

Coefficient of Determination

Model Summary

\begin{tabular}{|l|l|l|l|l|}
\hline Model & $\mathrm{R}$ & $\mathrm{R}$ Square & Adjusted R Square & Std. Error of the Estimate \\
\hline 1 & $.942 \mathrm{a}$ & .887 & .884 & .66173 \\
\hline a. Predictors: (Constant), X2, X1. &
\end{tabular}

Table 3 - Simultaneous Test

ANOVAa

\begin{tabular}{|l|l|l|l|l|l|}
\hline Model & Sum of Squares & df & Mean Square & F & Sig. \\
\hline Regression & 332.036 & 2 & 166,018 & 379,139 & $.000 \mathrm{~b}$ \\
Residual & 42,474 & 97 & 438 & & \\
Total & 374,510 & 99 & & & \\
\hline
\end{tabular}

a. Dependent Variable: $Y$.

b. Predictors: (Constant), X2, X1.

The results of the regression calculation can be seen that the adjusted $R$ square value is 0.884 . This means that $88.4 \%$ percent of the variation in the Income Increase variable (Y) can be explained by Digital Marketing (X1) and Business Capital (X2) variables while the remaining $11.6 \%$ percent is explained by other variables not included in this research model.

From the data above, it can be seen that the significance value is $0.000<0.05$, so it can be concluded that simultaneously, the Digital Marketing (X1) and Business Capital (X2) variables have an effect on the Income Increase variable.

The test results show the tcount $X 1(16,225)$ with a significant value of $0.000<0.05$, then $\mathrm{H} 0$ is rejected and $\mathrm{H} 1$ is accepted, so it can be concluded that there is a positive and partially significant effect between Digital Marketing variables on Income Increase.

The test results show the value of tcount X2 $(6,498)$ with a significant value of $0.000<$ 0.05 , then $\mathrm{HO}$ is rejected and $\mathrm{H} 1$ is accepted, it can be concluded that there is a partially significant effect between the variables of Business Capital on Increasing Income. 
Table 4 - T Uji test

Coefficients $^{a}$
\begin{tabular}{|l|l|l|l|l|l|}
\hline Model & Unstandardized Coefficients & Standardized Coefficients & & & Sig. \\
\cline { 2 - 6 } & $\mathrm{B}$ & Std. Error & Beta & & \\
\hline (Constant) & 3.498 & .652 & 1,453 & .763 & .447 \\
1 X1 & .139 & .070 & .582 & 16,225 & .000 \\
X2 & .542 & .083 & 6.498 & .000 \\
\hline
\end{tabular}

a. Dependent Variable: $Y$.

Based on the results of the analysis, it is concluded that the Digital Marketing variable has a positive and partially significant effect on increasing MSME income. Where the indicators used are ease of use, convenience of use, providing complete information, use of Facebook social media, use of Instagram social media, use of e-commerce. These results indicate that Digital Marketing is one of the factors that play an important role in determining the level of income that will be obtained by a business. In the midst of Covid-19, people are reluctant to shop out so that the use of digital marketing is very helpful in marketing products from MSMEs. If we do digital marketing, people will find it easier to get information about the products being sold so that the buying and selling transaction process increases. Purchases will increase and income will also increase.

Likewise, Business Capital has a positive and significant partial effect on increasing MSME income. Where this business capital consists of several indicators, namely obtaining capital on credit, the amount of capital, obstacles to capital sources, and sources of own capital and sources of capital from outside. These results indicate that business capital is one of the factors that play an important role in determining the level of income that will be obtained by a business. The higher the business capital, the more product variants that are sold so that more consumers come to shop, this will encourage an increase in MSME income.

\section{REFERENCES}

1. Abbas, Jamila. 2018. The Influence of Business Capital, Market Orientation, and Entrepreneurship Orientation on the Performance of Makassar City SMEs. Journal of Management, Ideas, Inspiration (MINDS). Vol.5, No. 1.

2. Artini, Ni Rai. 2019. Analysis of Factors Affecting MSME Income in Tabanan Regency. Journal of Unmas Mataram. Vol. 13 No. 1.

3. Gitman, LJ, Juchau, R., \& Flanagan, J. (2015). Principles of managerial finance. Pearson Higher Education AU.

4. Idawati, Ida Ayu Agung. Surya Primary. 2020. The Effect of Financial Literacy on the Performance and Sustainability of MSMEs in Denpasar City. Warmadewa Management and Business Journal. Vol. 2 No. 1.

5. Ningsih, Holy Ethics. 2018. The Effect of Financial Literacy on the Performance of Micro, Small and Medium Enterprises in Jember Regency. Thesis: University of Jember. Unpublished.

6. Sulaksono, July. Zakaria, Nisar. 2020. The Role of Digital Marketing for Micro, Small and Medium Enterprises (MSMEs) in Tales Village, Kediri Regency. Generation J. Vol.4 No.1.

7. Utari, Tri. Dewi, Putu Martini. 2014. The Influence of Capital, Education Level and Technology on Income of Micro, Small and Medium Enterprises (MSMEs) in the Imam Bonjol Area, West Denpasar. Unud EP E-Journal, 3 (12).

8. Wardhana, A. (2015). Digital Marketing Strategy and Its Implications on the Competitive Advantage of SMEs in Indonesia.

9. Electronic Source: http://ukmdiskop.denpasarkota.go.id. 